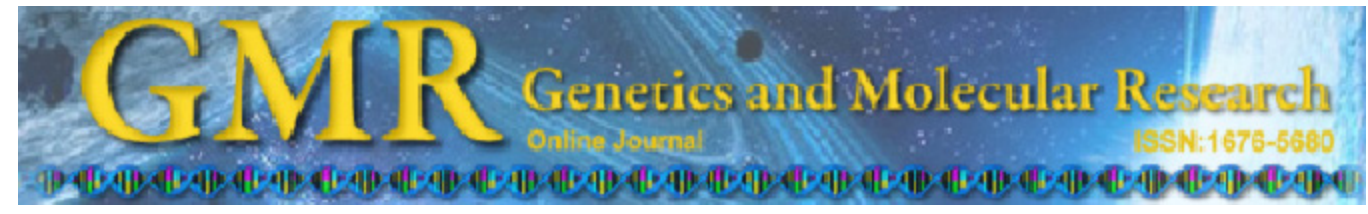

\title{
Role of Th1/Th2 cytokines in serum on the pathogenesis of chronic hepatitis $C$ and the outcome of interferon therapy
}

\author{
L. Zhang ${ }^{1 *}$, C.Q. Hao ${ }^{2 *}$, L. Miao ${ }^{1}$ and X.G. Dou ${ }^{1}$ \\ ${ }^{1}$ Department of Infectious Diseases, \\ Sheng Jing Hospital of China Medical University, Shenyang, China \\ ${ }^{2}$ Department of Infectious Diseases, Tangdu Hospital, \\ Fourth Military Medical University, Xi'an, China \\ *These authors contributed equally to this study. \\ Corresponding author: L. Zhang \\ E-mail: xiaoguangdoucn@163.com
}

Genet. Mol. Res. 13 (4): 9747-9755 (2014)

Received May 28, 2013

Accepted August 8, 2014

Published November 27, 2014

DOI http://dx.doi.org/10.4238/2014.November.27.2

\begin{abstract}
The aim of this study was to investigate the role of T-helper cell (Th)1/Th2 cytokines in the chronicity of hepatitis $\mathrm{C}$ virus (HCV) infection and the outcome of interferon (IFN) alpha therapy. A total of 30 patients with chronic hepatitis $\mathrm{C}$ were enrolled in the study. The levels of Th1/Th2 cytokines were determined. The differentiation of HCV genotypes was determined by direct sequencing. HCV RNA loads were detected by fluorescence quantitative polymerase chain reaction (qPCR). In chronic hepatitis $\mathrm{C}$, the levels of interleukin (IL)2 and transforming growth factor (TGF)- $\beta$ significantly decreased, and IL-5 and IL-18 levels increased compared with normal controls. The IL-6 serum levels were directly proportional to the serum levels of alanine aminotransferase, and were inversely proportional to the HCV RNA loading levels. Patients with severe hepatitis $\mathrm{C}$ had higher levels of IL-4, IL-6, and IL-1 $\beta$ compared to milder cases. Patients with genotype 1 showed higher serum levels of IL- 6 than those with
\end{abstract}


genotype 2 . The levels of IL-2 and IL-18 showed a decreasing tendency, whereas TGF- $\beta$, IL- 6 , and IL- $1 \beta$ showed an increasing tendency over time. There was no difference in any cytokines detected between the response and nonresponse groups before IFN therapy. However, the IFN- $\gamma$ level increased after IFN therapy in the response group. There was no correlation between the Th1/Th2 cytokine levels in the serum before IFN treatment and in the outcome of IFN therapy. Increasing IFN- $\gamma$ levels in the serum induced by IFN treatment is associated with systemic vascular resistance.

Key words: Th1/Th2 cell; Cytokine; Serum; Chronic hepatitis C; Pathogenesis; Interferon

\section{INTRODUCTION}

Hepatitic $\mathrm{C}$ virus (HCV) infection is a major cause of chronic hepatitis $\mathrm{C}(\mathrm{CH}-\mathrm{C})$. The rate of chronicity after acute HCV infection is above $80 \%$ (Alter et al., 1992; Seeff, 1995), and some patients will ultimately develop liver cirrhosis and hepatocellular carcinoma (Gane, 2008; Kwon and Bae, 2008; Masuzaki et al., 2008). Due to the high mutation rate of the HCV genome, effective vaccines have not yet been developed. The rate of the sustained virological response (SVR) to interferon (IFN) treatment is only approximately 40\% (Trepo, 2000; Kogure et al., 2008). Studies on the pathogenesis of CH-C and those aimed at improving the SVR rate of IFN treatment have long been research hot spots. The imbalance among T-helper (Th) cell subpopulations, Th1 and Th2, has been proposed to play a pivotal role in the development of chronic viral infections (Priı̌miagi et al., 2003; Falasca et al., 2007; Lapiński and Dabrowska, 2007). However, it is still controversial as to which Th cell subpopulation, Th1 or Th2, may contribute to its pathogenesis. Napoli et al. (1996) showed that IFN- $\gamma$ and interleukin (IL)-2 mRNA expressions in liver tissues from $\mathrm{CH}-\mathrm{C}$ patients were significantly upregulated, and were correlated with histological fibrosis and portal tract inflammation. On the other hand, the intrahepatic expression of IL-10 mRNA decreased. Napoli et al. (1996) concluded that the progressive liver injury in $\mathrm{CH}-\mathrm{C}$ is associated with the upregulation of intrahepatic Th1 cytokines and the downregulation of IL-10, a Th2 cytokine. Cacciarelli et al. (1996) demonstrated that the serum levels of Th2 cytokines were significantly increased in patients with $\mathrm{CH}-\mathrm{C}$, and were decreased by IFN therapy with a decrease in the HCV RNA load. In contrast, Inglot et al. (2008) reported that the serum levels of IL-2, IFN- $\gamma$, IL-4, and IL-10 of CH-C were not significantly different compared with normal controls, and could not be used to evaluate the outcomes of IFN treatment. This conflicting data shows that more research is needed to clarify these mechanisms. In the current study, the levels of Th1/Th2-related cytokines in the serum were investigated to clarify their roles on the pathogenesis of CH-C and the outcome of IFN therapy.

\section{MATERIAL AND METHODS}

\section{Patients}

A total of 30 patients with $\mathrm{CH}-\mathrm{C}$ were enrolled in the present study (15 males, $15 \mathrm{fe}-$ 
males; mean age $48.5 \pm 8.11$ years; Table 1). All patients were treated with a 48 -week course of IFN alpha-2b plus ribavirin combination therapy. A $50 \mu \mathrm{g}$ dose of Peg-IFN- $\alpha-2 b$ was intramuscularly injected once a week in eight patients. The other 22 patients received IFN- $\alpha-2 b$ at a dose of three million units (MU) three times a week. During IFN therapy, ribavirin was given orally at a dose of $800 \mathrm{mg}$ or $1000 \mathrm{mg}$ per day according to the patient's weight (800 $\mathrm{mg}$ for those weighing $<60 \mathrm{~kg}$ and $1000 \mathrm{mg}$ for those weighing $>60 \mathrm{~kg}$ ). Both drugs were withheld when the hemoglobin concentration decreased to $<8.5 \mathrm{~g} / \mathrm{dL}$, or when the neutrophil count was $<500 / \mathrm{mm}^{3}$ or the platelet count was $<25,000 / \mathrm{mm}^{3}$. Patients who were HCV-RNA negative at the 24th week after the completion of the IFN alpha-2b plus ribavirin combination therapy were declared as SVR.

All patients were divided into three groups according to their clinical manifestation and liver biopsy: mild (18 cases), intermediate ( 8 cases), and severe (4 cases).

\section{Cytokines determination}

Levels of the cytokines in serum, including IL-2, IFN- $\gamma$, transforming growth factor (TGF)- $\beta$, IL-4, IL-5, IL-6, IL-10, IL-18, and IL-1 $\beta$, were detected by enzyme-linked immunosorbent assay (ELISA) before IFN therapy. Twelve patients were dynamically monitored before and after IFN treatment. The HCV RNA load in the serum was detected by fluorescence quantitative polymerase chain reaction (qPCR).

\section{Genotype}

Genotype was classified according to the nucleotide sequences of the NS5B region. HCV RNA was extracted from serum samples and used for the genome amplification of the partial NS5B region by nested reverse transcriptase (RT)-PCR. PCR products were purified and directly sequenced employing an ABI 3130 xl Genetic Analyzer with the Bid Dye Terminator Cycle Sequencing kit (Applied Biosystems, Inc.). The nucleotide sequences were analyzed with the MEGA software.

\section{Statistical analysis}

Statistical analysis was performed with SPSS 15.0. Differences between the two groups were evaluated by using an analysis of variance (ANOVA) table and an eta-squared test. Correlation analysis was performed by using the bivariate correlations method. P values $<0.05$ were considered to be statistically significant.

\section{RESULTS}

\section{Characteristics of patients}

The SVR rate of the patients who were treated with IFN plus ribavirin combination therapy was $46.7 \%$. As shown in Table 1, the patients were finally divided into a complete responders $(\mathrm{CR})$ group $(\mathrm{N}=14)$ and a non-responders $(\mathrm{NR})$ group $(\mathrm{N}=16)$ at 6 months after the end of IFN therapy. Serum alanine aminotransferase (ALT) levels were significantly higher in 
the CR group, being almost twice as high as those in the NR group. The pretreatment viral load was not significantly different between the two groups. Genotype $1 \mathrm{~b}$ was more frequent in the NR group. Other parameters, including gender, age, weight, and time of infection showed no difference between the two groups. Patients treated with Peg-IFN- $\alpha-2 b$ showed a higher SVR rate $(62.5 \%)$ compared with those treated with IFN- $\alpha-2 b$ (40.9\%); however, the difference was not statistically significant.

\begin{tabular}{|c|c|c|c|}
\hline Variables & CR group & NR group & $P$ value \\
\hline Cases & 14 & 16 & \\
\hline Age (year) & $51.43 \pm 9.053$ & $45.94 \pm 6.403$ & 0.063 \\
\hline Gender (male \%) & $50 \%$ & $50 \%$ & 0.642 \\
\hline Weight $(\mathrm{kg})$ & $62.96 \pm 11.22$ & $61.06 \pm 12.21$ & 0.662 \\
\hline Infection time (year) & $11.96 \pm 9.45$ & $15.43 \pm 7.17$ & 0.298 \\
\hline $\operatorname{ALT}(\mu / \mathrm{L})$ & $124.86 \pm 99.42$ & $65.44 \pm 53.99$ & 0.048 \\
\hline HCV RNA load (lg copies $/ \mathrm{mL}$ ) & $6.32 \pm 0.828$ & $6.08 \pm 0.892$ & 0.460 \\
\hline \multicolumn{4}{|l|}{ IFN type } \\
\hline Peg- $\alpha-2 b$ & $5 / 8(62.5 \%)$ & $3 / 8(37.5 \%)$ & \\
\hline$a-2 b$ & $9 / 22(40.9 \%)$ & $13 / 22(59.1 \%)$ & 0.417 \\
\hline \multicolumn{4}{|l|}{ HCV genotype } \\
\hline $1 \mathrm{a}$ & $2 / 4(50 \%)$ & $2 / 4(50 \%)$ & \\
\hline $1 \mathrm{~b}$ & $5 / 14(35.7 \%)$ & $9 / 14(64.3 \%)^{*}$ & 0.336 \\
\hline $1 \mathrm{c}$ & 0 & $1 / 1(100 \%)$ & \\
\hline $2 \mathrm{a}$ & $4 / 6(66.7 \%)$ & $2 / 6(33.3 \%)^{*}$ & \\
\hline $2 \mathrm{~b}$ & $1 / 3(33.3 \%)$ & $2 / 3(66.7 \%)$ & \\
\hline $3 \mathrm{a}$ & $2 / 2(100 \%)$ & 0 & \\
\hline
\end{tabular}

*Comparison of genotypes $1 \mathrm{~b}$ and $2 \mathrm{a}$.

\section{Relationship between Th1/Th2 cytokines and CH-C}

As shown in Table 2, the levels of IL-2 and TGF- $\beta$ in serum were significantly decreased, and IL-5 and IL-18 levels increased in patients with CH-C compared with those in the normal control group. There was no difference in the levels of the other cytokines, including IFN- $\gamma$, IL-4, IL-6, IL-10, and IL-1 $\beta$, between the two groups.

The serum level of IL-6 was directly proportional to the serum levels of ALT ( $\mathrm{r}=$ $0.441, \mathrm{P}=0.015)$, and was inversely proportional to the HCV RNA load $(\mathrm{r}=-4.86, \mathrm{P}=0.006)$. Patients with severe cases showed higher levels of IL-4 (1.90 $\pm 0.09 \mathrm{pg} / \mathrm{mL})$, IL-6 (5.20 \pm 2.04 $\mathrm{pg} / \mathrm{mL})$, and IL-1 $\beta(5.28 \pm 1.91 \mathrm{pg} / \mathrm{mL})$ compared to patients with mild cases $(1.53 \pm 0.21 \mathrm{pg} /$ $\mathrm{mL}, \mathrm{P}=0.026 ; 4.02 \pm 0.67 \mathrm{pg} / \mathrm{mL}, \mathrm{P}=0.050 ; 3.71 \pm 0.75 \mathrm{pg} / \mathrm{mL}, \mathrm{P}=0.019$, respectively).

Patients with genotype 1 showed higher IL-6 serum levels $(4.41 \pm 0.83 \mathrm{pg} / \mathrm{mL})$ compared to those with genotype $2(3.72 \pm 0.34 \mathrm{pg} / \mathrm{mL}, \mathrm{P}<0.05)$, whereas patients with genotype 2a showed lower IL-2 serum levels $(0.33 \pm 0.14 \mathrm{pg} / \mathrm{mL})$ than those with genotype $2 \mathrm{~b}(0.58 \pm$ $0.10 \mathrm{pg} / \mathrm{mL} ; \mathrm{P}<0.05)$.

All patients were classified into four groups according to the time of HCV infection, including 0-5 years, 6-10 years, 11-20 years, and 21-30 years. The serum levels of cytokines among the groups were compared. Patients in the 0-5-year group showed a higher IL-2 serum level $(0.50 \pm 0.13 \mathrm{pg} / \mathrm{mL})$ and a lower TGF- $\beta$ level $(186.66 \pm 115.53 \mathrm{pg} / \mathrm{mL})$ compared with the 11-20-year group $(0.32 \pm 0.17 \mathrm{pg} / \mathrm{mL}, \mathrm{P}=0.021$ and $270.77 \pm 67.09 \mathrm{pg} / \mathrm{mL}, \mathrm{P}=0.047$, respectively). Patients in the 0-5-year group also showed lower IL-6 $(3.94 \pm 0.47 \mathrm{pg} / \mathrm{mL})$ and 
IL-1 $\beta(3.63 \pm 0.42 \mathrm{pg} / \mathrm{mL})$ levels compared with the $21-30$-year group $(5.43 \pm 1.72 \mathrm{pg} / \mathrm{mL}$, $\mathrm{P}=0.05$ and $6.56 \pm 0.99 \mathrm{pg} / \mathrm{mL}, \mathrm{P}=0.000$, respectively). Patients in the 6-10-year group showed higher IL-18 serum levels $(1936.50 \pm 705.83 \mathrm{pg} / \mathrm{mL})$ compared with the 11-20-year group $(872.35 \pm 703.30 \mathrm{pg} / \mathrm{mL}, \mathrm{P}=0.031)$. The serum level of TGF- $\beta$ in the 21 -30-year group $(121.38 \pm 18.50 \mathrm{pg} / \mathrm{mL})$ was decreased and that of IL-6 $(5.43 \pm 1.72 \mathrm{pg} / \mathrm{mL})$ was increased compared to those of the 11-20-year group $(270.77 \pm 67.09 \mathrm{pg} / \mathrm{mL}, \mathrm{P}=0.009$ and $3.98 \pm 0.62$ $\mathrm{pg} / \mathrm{mL}, \mathrm{P}=0.024$, respectively). The trend of changes in all cytokine levels across different phases after HCV infection is shown in Figure 1.

Table 2. Comparison of levels of Th1/Th2 cytokines in serum between patients with chronic hepatitis $\mathrm{C}$ and normal control.

\begin{tabular}{lccc}
\hline Variables & Chronic hepatitis C $(\mathrm{pg} / \mathrm{mL})$ & Normal control $(\mathrm{pg} / \mathrm{mL})$ & P value \\
\hline IL-2 & $0.40 \pm 0.18$ & $1.40 \pm 1.04$ & 0.000 \\
IFN- $\gamma$ & $8.85 \pm 4.71$ & $11.19 \pm 15.78$ & 0.418 \\
TGF- $\beta$ & $272.28 \pm 166.98$ & $551.10 \pm 240.07$ & 0.000 \\
IL-4 & $1.60 \pm 0.21$ & $1.63 \pm 0.24$ & 0.642 \\
IL-5 & $86.97 \pm 34.46$ & $56.54 \pm 40.87$ & 0.015 \\
IL-6 & $4.18 \pm 0.69$ & $3.59 \pm 1.30$ & 0.470 \\
IL-10 & $5.77 \pm 0.86$ & $10.48 \pm 17.36$ & 0.107 \\
IL-18 & $1077.44 \pm 657.58$ & $259.92 \pm 328.47$ & 0.000 \\
IL-1 $\beta$ & $3.88 \pm 0.93$ & $3.44 \pm 1.36$ & 0.209 \\
\hline
\end{tabular}
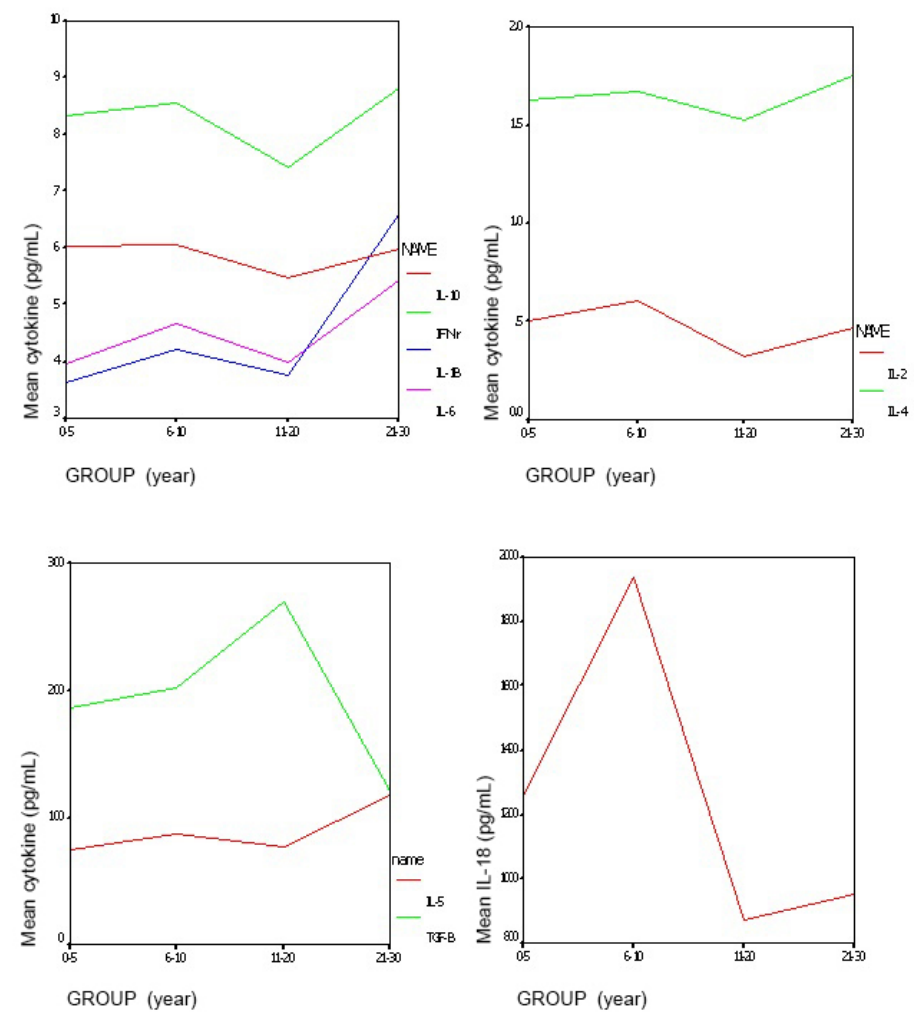

Figure 1. Relationship betwen levels of cytokines in serum and time of HCV infection. 


\section{Relationship between Th1/Th2-related cytokines and the outcome of IFN therapy}

To investigate whether the final outcome of IFN therapy might be affected by the pretreatment levels of these cytokines, differences in the CR and NR groups were retrospectively analyzed. Serum levels of all cytokines tested before IFN treatment in the CR group were not different from those in the NR group (Table 3). Twelve of the 30 patients were dynamically observed before and after IFN therapy. Five of them were CRs and 7 were NRs. In the CR group, the level of IFN- $\gamma$ increased after IFN treatment compared with pretreatment levels. None of the serum cytokines showed a significant difference in the NR group before and after IFN treatment (Table 4).

\begin{tabular}{|c|c|c|c|}
\hline Cytokines & $\mathrm{CR}$ group $(\mathrm{pg} / \mathrm{mL})$ & NR group $(\mathrm{pg} / \mathrm{mL})$ & $P$ value \\
\hline IL-2 & $0.46 \pm 0.15$ & $0.37 \pm 0.21$ & 0.183 \\
\hline IFN- $\gamma$ & $8.10 \pm 1.19$ & $7.97 \pm 1.27$ & 0.771 \\
\hline TGF- $\beta$ & $195.53 \pm 103.86$ & $284.68 \pm 157.43$ & 0.082 \\
\hline IL-4 & $1.61 \pm 0.17$ & $1.57 \pm 0.26$ & 0.641 \\
\hline IL-5 & $77.60 \pm 32.47$ & $85.81 \pm 28.75$ & 0.469 \\
\hline IL-6 & $4.015 \pm 0.46$ & $4.29 \pm 0.93$ & 0.326 \\
\hline IL-10 & $5.79 \pm 0.57$ & $19.73 \pm 56.89$ & 0.368 \\
\hline IL- $1 \beta$ & $3.81 \pm 0.88$ & $4.05 \pm 1.06$ & 0.493 \\
\hline IL-18 & $1091.57 \pm 610.16$ & $1180.25 \pm 787.13$ & 0.736 \\
\hline
\end{tabular}

Table 4. Comparison of levels of Th1/Th2 related cytokines in serum before and after interferon (IFN) therapy.

\begin{tabular}{|c|c|c|c|}
\hline Variable & $\begin{array}{l}\text { Before IFN treatment } \\
(\mathrm{pg} / \mathrm{mL})\end{array}$ & $\begin{array}{l}\text { After IFN treatment } \\
\qquad(\mathrm{pg} / \mathrm{mL})\end{array}$ & $P$ value \\
\hline \multicolumn{4}{|l|}{ CR group } \\
\hline IL-2 & $0.43 \pm 0.18$ & $0.31 \pm 0.15$ & 0.276 \\
\hline IFN- $\gamma$ & $7.36 \pm 0.57$ & $8.40 \pm 0.67$ & 0.030 \\
\hline TGF- $\beta$ & $188.80 \pm 78.21$ & $298.54 \pm 123.29$ & 0.131 \\
\hline IL-4 & $1.53 \pm 0.15$ & $1.59 \pm 0.28$ & 0.662 \\
\hline IL-5 & $73.21 \pm 31.42$ & $60.25 \pm 17.87$ & 0.446 \\
\hline IL-6 & $3.96 \pm 0.38$ & $5.72 \pm 2.77$ & 0.197 \\
\hline IL-10 & $5.58 \pm 0.44$ & $5.50 \pm 0.50$ & 0.803 \\
\hline IL-1 $\beta$ & $3.88 \pm 1.48$ & $2.84 \pm 0.64$ & 0.186 \\
\hline IL-18 & $1161.50 \pm 578.88$ & $1186.10 \pm 625.57$ & 0.950 \\
\hline \multicolumn{4}{|l|}{ NR group } \\
\hline IL-2 & $0.33 \pm 0.28$ & $0.38 \pm 0.19$ & 0.698 \\
\hline IFN- $\gamma$ & $7.10 \pm 0.84$ & $7.43 \pm 0.91$ & 0.502 \\
\hline TGF $-\beta$ & $330.99 \pm 207.43$ & $341.84 \pm 98.45$ & 0.903 \\
\hline IL-4 & $1.43 \pm 0.15$ & $1.57 \pm 0.18$ & 0.150 \\
\hline IL-5 & $80.53 \pm 30.52$ & $79.49 \pm 21.56$ & 0.942 \\
\hline IL-6 & $4.08 \pm 0.90$ & $3.31 \pm 0.47$ & 0.069 \\
\hline IL-10 & $5.66 \pm 1.44$ & $5.19 \pm 0.83$ & 0.475 \\
\hline IL-1 $\beta$ & $3.95 \pm 1.04$ & $4.46 \pm 0.98$ & 0.364 \\
\hline IL-18 & $1147.36 \pm 738.29$ & $740.07 \pm 333.84$ & 0.208 \\
\hline
\end{tabular}

\section{DISCUSSION}

There is accumulating evidence that $\mathrm{HCV}$-specific Th cell responses may regulate the antiviral immune response not only by the induction of virus-specific class I-restricted cyto- 
toxic $\mathrm{T}$ lymphocytes and anti-HCV antibody producing $\mathrm{B}$ cells, but also by the interaction with infected hepatocytes via cytokines (Koziel et al., 1995); however, the mechanism is not completely understood. Recently, the imbalance among the Th cell subpopulations, Th- 1 and Th-2, were proposed to play a pivotal role in the development of $\mathrm{CH}-\mathrm{C}$, and to affect the outcome of IFN treatment. Th1 cells produce IFN- $\gamma$, TGF- $\beta$, and IL- 2 , and are associated with cell-mediated immunity. Th2 cells produce IL-4, IL-5, IL-6, and IL-10, which are mostly responsible for regulating humoral immune responses (Mosmann et al., 1986). One striking hypothesis claims that an imbalance in the Th1-Th2 helper cell responses is a critical factor that could lead to viral persistence, but the data are not consistent. Cacciarelli et al. (1996) showed that the serum levels of Th- 1 cytokines (IFN- $\gamma$ and IL-2) and Th-2 cytokines (IL-4 and IL-10) were elevated, and that the extent of the increase in the latter cytokines was more prominent. Reiser et al. (1997) also showed that the serum levels of Th-2 cytokines (IL-4 and IL-10) increased as a systemic response, and did not correlate with the numbers of locally infiltrating Th-2 subpopulations in the liver. Napoli et al. (1996) reported that the intrahepatic mRNA expressions of IFN- $\gamma$ and IL-2 were upregulated and correlated with histological fibrosis and portal tract inflammation, whereas those of IL-10 were downregulated. In the present study, the serum levels of Th1/ Th 2 cytokines, including IL-2, IFN- $\gamma$, TGF- $\beta$, IL-4, IL-5, IL-6, and IL-10, were determined by ELISA. The levels of IL- 2 and TGF- $\beta$ decreased and IL- 5 was increased in patients with $\mathrm{CH}-\mathrm{C}$ compared with the normal controls. All cytokines were also compared among different groups varying in $\mathrm{HCV}$ infection time: 0-5 years, 6-10 years, 11-20 years, and 21-30 years. The levels of IL- 2 and TGF- $\beta$ showed a tendency to decrease, whereas IL-6 levels tended to increase over infection time. Results showed that insufficient Th1 cell induction and reinforced Th2- cell activities might be correlated with viral persistence in chronic $\mathrm{HCV}$ infections.

The relationship between Th1/Th2 cytokines and the clinical manifestations was also analyzed. The level of IL-6 was directly proportional to the serum levels of ALT, whereas it was inversely proportional to that of the HCV RNA load. The severe patients showed higher levels of IL-4 and IL- 6 compared to mild cases. Patients with genotype 1 had higher sera quantities of IL-6 than those with genotype 2, whereas patients with genotype 2a had lower sera quantities of IL-2 than did those with genotype $2 b$. These data indicated that Th2 cytokines may play an important role in the inflammation of the liver and in the persistence of HCV infection. IL-6 was not only related to the chronicity of HCV infection but also with the active inflammation of the liver. However, it is still unknown whether this is also one of the factors contributing to the higher rate of chronicity in patients with $\mathrm{HCV}$ genotype 1 infection compared to those with genotype 2 (Amoroso et al., 1998).

IL-1 8 and IL-1 $\beta$ are produced by mononuclear macrophages. The two cytokines can activate Th1 cells and take part in the pathogenesis of HCV infection (Akira, 2000; McGuinness et al., 2000). In the present study, the level of IL-18 in the serum of the CH-C group was higher than that of the healthy control group, and was positively related to the level of IL-2 (data not shown). The level of IL-1 $\beta$ did not differ between the two groups; however, it showed a tendency to increase after HCV infection, whereas IL-18 showed a tendency to decrease. These results indicated that IL-18 and IL-1 $\beta$ may be correlated with the chronicity of hepatitis C. The level of IL- $1 \beta$ increased in patients with severe hepatitis $\mathrm{C}$ compared to that in the mild cases. Therefore, IL- $1 \beta$ is an indicator that can reflect the severity of CH-C. The results were consistent, in part, with those reported by Falasca et al. (2006) and MajdaStanisławska et al. (2008). In contrast, Schvoerer et al. (2003) reported that the level of IL18 , not only in serum, but also in peripheral blood mononuclear cells, was lower than that in 
normal controls, and was associated with the active inflammation of the liver. Lapiński (2001) showed that the level of IL- $1 \beta$ in serum was increased compared with that of normal controls, and had no relationship with the degree of liver inflammation and fibrosis. In conclusion, IL18 and IL-1 $\beta$, together with Th1/Th2 cytokines, make up a complex network system affecting the pathogenesis of $\mathrm{CH}-\mathrm{C}$. The controversial results should be tested through further study.

Many studies have demonstrated immunological parameters that could predict the action of IFN and ribavirin combination therapy. Trapero et al. (2005) reported that the cytokine T1-induced response maintenance during IFN and ribavirin combination treatment, measured as IFN- $\gamma$, was associated with SVR, which suggested a role in the replication control and later clearance of patients infected by genotype-1 HCV. Bozkaya et al. (2000) reported that the decreasing serum levels of sIL-2R and IL-10 were important for predicting the CR to IFN treatment. However, there are still conflicting results. Bozkaya et al. (2000) suggested that active liver injury in CH-C is associated with the increased circulation of Th1 cytokine IL-2 levels, but not with Th2 cytokine IL-10 levels, and that the circulating levels of these cytokines do not predict the response to IFN treatment. There is no consistent and regular change in the circulating levels of these cytokines under IFN treatment with respect to treatment response. In the current study, the serum Th1/Th2 cytokine levels in the CR group were compared with those of the NR group before IFN treatment, and changes in these cytokines after IFN therapy were investigated. The levels of all cytokines tested before IFN treatment in the CR group were not different from those in the NR group. In the CR group, the level of IFN- $\gamma$ increased after IFN treatment compared with pretreatment levels. None of the cytokines showed a significant difference in the NR group before and after IFN treatment. These results indicated that the levels of Th1/Th2 cytokines in the serum before IFN treatment could not predict the outcome of IFN therapy. Increasing IFN- $\gamma$ levels in the serum induced by IFN treatment was associated with the SVR. Results from previous reports are not completely consistent, which might be explained by differences in the methods used among studies. First, different methods, such as ELISA, radioimmunoassay, and flow cytometry, were used to evaluate levels in the peripheral blood and liver, and there is a possibility that Th1 is mobilized in the liver and that Th2 inversely increased in the peripheral blood. Second, different analytical methods were used in comparing the average value and changes in individual cases.

In summary, the imbalance of Th1/Th2 cytokines plays an important role not only in the pathogenesis and progression of $\mathrm{CH}-\mathrm{C}$, but also in the outcome of IFN therapy. Due to the complexity of the cytokine network system, there is still no accurate conclusion about the roles of these cytokines in disease progression and therapy at present. Further study is needed to clarify these mechanisms, which will be beneficial for developing effective antiviral treatment.

\section{ACKNOWLEDGMENTS}

Research supported by Science and Technology Project of Shenyang City (\#F12-193-9-27).

\section{REFERENCES}

Akira S (2000). The role of IL-18 in innate immunity. Curr. Opin. Immunol. 12: 59-63.

Alter MJ, Margolis HS, Krawczynski K, Judson FN, et al. (1992). The natural history of community-acquired hepatitis $\mathrm{C}$ in the United States. The Sentinel Counties Chronic non-A, non-B Hepatitis Study Team. N. Engl. J. Med. 327: 1899-1905. 
Amoroso P, Rapicetta M, Tosti ME, Mele A, et al. (1998). Correlation between virus genotype and chronicity rate in acute hepatitis C. J. Hepatol. 28: 939-944.

Bozkaya H, Bozdayi AM, Aslan N, Turkay C, et al. (2000). Circulating IL-2 and IL-10 in chronic active hepatitis C with respect to the response to IFN treatment. Infection 28: 309-313.

Cacciarelli TV, Martinez OM, Gish RG, Villanueva JC, et al. (1996). Immunoregulatory cytokines in chronic hepatitis C virus infection: pre- and posttreatment with interferon alfa. Hepatology 24: 6-9.

Falasca K, Ucciferri C, Dalessandro M, Zingariello P, et al. (2006). Cytokine patterns correlate with liver damage in patients with chronic hepatitis B and C. Ann. Clin. Lab. Sci. 36: 144-150.

Falasca K, Mancino P, Ucciferri C, Dalessandro M, et al. (2007). Inflammatory cytokines and S-100b protein in patients with hepatitis C infection and cryoglobulinemias. Clin. Invest. Med. 30: E167-E176.

Gane EJ (2008). The natural history of recurrent hepatitis C and what influences this. Liver Transpl. 14 (Suppl 2): S36-S44.

Inglot M, Gladysz A, Rymer W, Molin I, et al. (2008). Cytokine assessment in untreated hepatitis C virus infected patients and during interferon alpha+ribavirine therapy. Wiad. Lek. 61: 13-18.

Kogure T, Ueno Y, Fukushima K, Nagasaki F, et al. (2008). Pegylated interferon plus ribavirin for genotype Ib chronic hepatitis C in Japan. World J. Gastroenterol. 14: 7225-4230.

Koziel MJ, Dudley D, Afdhal N, Grakoui A, et al. (1995). HLA class I-restricted cytotoxic T lymphocytes specific for hepatitis $\mathrm{C}$ virus. Identification of multiple epitopes and characterization of patterns of cytokine release. J. Clin. Invest. 96: 2311-2321.

Kwon JH and Bae SH (2008). Current status and clinical course of hepatitis C virus in Korea. Korean J. Gastroenterol. 51: 360-367.

Lapiński TW (2001). The levels of IL-1beta, IL-4 and IL-6 in the serum and the liver tissue of chronic HCV-infected patients. Arch. Immunol. Ther. Exp. 49: 311-316.

Lapiński TW and Dabrowska MM (2007). Activity of cytokines in chronic HCV-infected patients. Przegl. Epidemiol. 61: 747-754.

Majda-Stanisławska E, Pietrzak A and Brzezinska-Blaszczyk E (2008). Serum IL-18 concentration does not depend on the presence of HCV-RNA in serum or in PBMC. Hepatogastroenterology 55: 212-215.

Masuzaki R, Tateishi R, Yoshida H, Yoshida H, et al. (2008). Risk assessment of hepatocellular carcinoma in chronic hepatitis C patients by transient elastography. J. Clin. Gastroenterol. 42: 839-843.

McGuinness PH, Painter D, Davies S and McCaughan GW (2000). Increases in intrahepatic CD68 positive cells, MAC387 positive cells, and proinflammatory cytokines (particularly interleukin 18) in chronic hepatitis C infection. Gut 46: 260-269.

Mosmann TR, Cherwinski H, Bond MW, Giedlin MA, et al. (1986). Two types of murine helper T cell clone. I. Definition according to profiles of lymphokine activities and secreted proteins. J. Immunol. 136: 2348-2357.

Napoli J, Bishop GA, McGuinness PH, Painter DM, et al. (1996). Progressive liver injury in chronic hepatitis C infection correlates with increased intrahepatic expression of Th1-associated cytokines. Hepatology 24: 759-765.

Prĭmiagi LS, Tefanova VT, Tallo TG, Shmidt EV, et al. (2003). Immune-regulating Th1- and Th2-cytokines in chronic infections caused by hepatitis B and C viruses. Vopr. Virusol. 48: 37-40.

Reiser M, Marousis CG, Nelson DR, Lauer G, et al. (1997). Serum interleukin 4 and interleukin 10 levels in patients with chronic hepatitis C virus infection. J. Hepatol. 26: 471-478.

Schvoerer E, Navas MC, Thumann C, Fuchs A, et al. (2003). Production of interleukin-18 and interleukin-12 in patients suffering from chronic hepatitis C virus infection before antiviral therapy. J. Med. Virol. 70: 588-593.

Seeff LB (1995). Natural history of viral hepatitis, type C. Semin. Gastrointest. Dis. 6: 20-27.

Trapero M, García-Buey L, Muñoz C, Vitón M, et al. (2005). Maintenance of T1 response as induced during PEGIFNalpha plus ribavirin therapy controls viral replication in genotype-1 patients with chronic hepatitis C. Rev. Esp. Enferm. Dig. 97: 481-490.

Trepo C (2000). Genotype and viral load as prognostic indicators in the treatment of hepatitis C. J. Viral Hepat. 7: 250257. 